\title{
PENGARUH TERAPI BERKEBUN TERHADAP PERUBAHAN TEKANAN DARAH PADA LANSIA DENGAN HIPERTENSI DI PANTI SOSIAL TRESNA WERDHA MINAULA KENDARI
}

\author{
Magfirah $^{1)}$, La Ode Alifariki ${ }^{2)}$ \\ ${ }^{1,2}$ Program Studi Keperawatan Fakultas Kedokteran Fakultas Kedokteran UHO \\ Kampus Bumi Tridharma Anduonuhu Kendari \\ E-mail: ners_riki@yahoo.co.id
}

\begin{abstract}
ABSTRAK
Penuaan dan penurunan fisiologis terjadi pada lansia karena proses degeneratif sehingga penyakit tidak menular seperti hipertensi sering diderita oleh lansia. Terapi berkebun adalah salah satu metode yang dapat digunakan sebagai terapi alternatif untuk menormalkan tekanan darah. Penelitian ini bertujuan untuk mengetahui pengaruh terapi berkebun terhadap perubahan tekanan darah Lansia dengan hipertensi.

Desain penelitian menggunakan quasi eksperimental pre-post test dengan kelompok kontrol dengan jumlah sampel sebanyak 15 responden yang dipilih secara purposive sampling. Variabel bebas dalam penelitian ini adalah terapi berkebun dan variabel dependennya adalah tekanan darah sistolik dan diastolik yang diukur dengan sphygmomanometer dan stetoskop. Data dianalisis dengan menggunakan uji t berpasangan dan uji t independen $(\alpha=0,05)$. Hasil analisis bivariat pada empat pertemuan menunjukkan bahwa ada pengaruh terapi berkebun terhadap perubahan tekanan darah sistolik diastolik pada pengukuran pertama, ketiga, keempat, sedangkan untuk tekanan darah sistolik ketiga, keempat untuk tekanan darah diastolik yang digambarkan oleh nilai $\mathrm{p}$ berikut, $\mathrm{p} 1=0,005$, $\mathrm{p} 3=0,015, \mathrm{p} 4=0,017$ dan $\mathrm{p} 3=0,018$ dan $\mathrm{p} 4=0,025$. Analisis perbedaan pada empat pertemuan menunjukkan bahwa ada perbedaan tekanan darah sistolik antara kelompok kontrol dan intervensi pada pertemuan ketiga di Institusi Sosial Tresna Werdha Minaula Kendari yang diwakili oleh nilai $\mathrm{p}$ berikut, $\mathrm{p} 3 \mathrm{TDS}=0,045$. Kesimpulan dari penelitian ini adalah bahwa terapi berkebun efektif untuk menormalkan tekanan darah lansia dengan hipertensi, sehingga diharapkan lansia harus mengambil terapi berkebun sebagai salah satu alternatif terapi nonfarmakologi yang dapat dilakukan secara mandiri atau bersama. tanpa menyebabkan efek samping.
\end{abstract}

Kata Kunci: Terapi Berkebun, Tekanan Darah Lansia

\begin{abstract}
ABSTRAK
The Human aging and the decline of physiological occur in the elderly due to degenerative process. Non-communicable diseases such as hypertension is often suffered by the elderly. Gardening therapy is one of the methods that can be used as an alternative to normalize the blood pressure. The purpose of this research is to examine the effects of gardening therapy on the changes in elderly blood pressure with hypertension.The research design used Quasy experimental pre post test with control group and the total sample of 15 respondents are selected by using purposive sampling. The independent variable in this study is the gardening therapy and the dependent variable is the systolic and diastolic blood pressure as measured by sphygmomanometer and stethoscope. The data were analyzed by using paired t-test and independent t-test $(\alpha=0.05)$. The results of bivariate analysis in this study showed that there was an effect of the gardening therapy on the changes in systolic and diastolic blood pressure in the first, third, and fourth measurements, while for systolic diastolic which was described by the following $p$ value, $p 1$ $=0.005, p 3=0.015, p 4=0.017$ and $p 3=0.018$ and $p 4=0.025$. The analysis of difference
\end{abstract}


in the four meetings showed that there were differences between control group and systolic blood pressure between the control group and the intervention at the third meeting at Institusi Sosial Tresna Werdha Minaula Kendari which was represented by the following $p$ value, $p 3 T D S=0.045$. The conclusion of this study is that the gardening therapy is an effective way to normalize the blood of elderly people with hypertension, so it is necessary to do the therapy as an alternative non-pharmacological therapy that can be done independently or together without causing side effects.

Key Words: Gardening therapy, elderly blood pressure.

\section{PENDAhUluan}

Menurut WHO, lanjut usia (lansia) adalah kelompok penduduk yang berumur 60 tahun atau lebih. Makin baiknya pelayanan kesehatan, maka ada kecenderungan meningkatnya umur harapan hidup sehingga berdampak pada semakin meningkatnya populasi Lansia dari tahun ke tahun.

Data World Population Prospects the 2015 Revision, jumlah lansia di dunia pada tahun 2015 dan 2030 jumlah orang berusia 60 tahun lebih diproyeksikan akan tumbuh sekitar 56\% dari 901 juta menjadi 1,4 milyar dan pada tahun 2050 populasi lansia diproyeksikan lebih dari 2 kali lipat di tahun 2015, yaitu mencapai 2,1 milyar. Selama 15 tahun kedepan, jumlah lansia diperkirakan akan meningkat. Amerika latin dan Karibia dengan proyeksi peningkatan $71 \%$, penduduk usia 60 tahun atau lebih diikuti oleh Asia 66\%, Afrika 64\%, Ocemia 47\%, Amerika Utara $41 \%$ dan Eropa 23\%. Hal ini akan cenderung meningkatkan angka prevalensi kejadian penyakit degeneratif (Nations, 2015).

Jumlah lansia di Indonesia pada tahun 2000 meningkat menjadi 14,4 juta jiwa $(7,18 \%)$ dari jumlah penduduk di Indonesia dengan usia harapan hidup 66,2 tahun. Pada tahun 2006 angka meningkat hingga dua kali lipat menjadi 19 juta jiwa $(8,9 \%)$ dari jumlah penduduk di Indonesia dengan usia harapan hidup 66,2 dan diperkirakan tahun 2020 mencapai 28,8 juta jiwa $(11,34 \%)$ dari jumlah penduduk di Indonesia dengan usia harapan hidup 71,1 tahun (Agustina, 2014).

Peningkatan jumlah lansia di Indonesia ini memberikan suatu perhatian khusus pada lansia yang mengalami suatu proses menua. Permasalahan-permasalahan yang perlu perhatian khusus untuk lansia berkaitan dengan berlangsungnya proses menjadi tua, yang berakibat timbulnya perubahan fisik, kognitif, perasaan, sosial, dan seksual (Agustina, 2014). Pertambahan usia dan penurunan fisiologis terjadi pada lansia akibat proses degeneratif (penuaan) sehingga penyakit tidak menular banyak muncul pada usia lanjut. Penyakit tidak menular pada lansia di antaranya hipertensi, stroke, diabetes melitus dan radang sendi atau rematik. Hipertensi merupakan "silent killer" sehingga menyebabkan fenomena gunung es. Prevalensi hipertensi meningkat dengan bertambahnya usia. Kondisi patologis ini jika tidak mendapatkan penanganan secara cepat dan secara dini maka akan memperberat risiko (Wahyuningsih dan Astuti E., 2013).

Menurut data WHO, di seluruh dunia, sekitar 972 juta orang atau $26,4 \%$ penghuni bumi mengidap hipertensi, angka ini kemungkinan akan meningkat menjadi 29,2\% di tahun 2025, dari 972 juta pengidap hipertensi 333 juta berada di negara berkembang, termasuk Indonesia, sehingga berdampak pada meningkatnya beban tangggungan keluarga Lansia (Yonata \& Pratama, 2016).

Hipertensi adalah penyakit yang perlu diberikan penanganan ekstra karena jika tidak dapat berdampak pada kesehatan khususnya kesehatan lansia. Hipertensi merupakan faktor risiko utama terjadinya penyakit jantung, gagal jantung kongestif, stroke, gangguan penglihatan dan penyakit ginjal. Komplikasi yang terjadi pada hipertensi ringan dan sedang yaitu pada mata, ginjal, jantung dan otak. Komplikasi pada mata berupa perdarahan retina, gangguan penglihatan sampai dengan kebutaan $(\mathrm{H}$ \& Nisa, 2017). 
Cara pengendalian tekanan darah selain dari obat antihipertensi juga diimbangi dengan merubah gaya hidup lebih sehat, melakukan aktivitas fisik, dan manajemen stress dengan melakukan hal yang menyenangkan seperti melakukan hobi atau kegiatan yang diminati. Berkebun merupakan metode yang dapat dijadikan sebagai alternatif rekreasi yang cocok dengan aktivitas gaya hidup sehat. Melakukan sesuatu yang didasari oleh hobi akan lebih mudah dilakukan karena tidak dijadikan sebagai beban, atau tuntutan yang malah memberatkan lansia. Salah satu hobi yang biasa dijadikan sebagai alternatif terapi adalah berkebun (Sari A.P. dkk. 2014).

Penelitian yang dilakukan oleh Ayu Permata Sari di Magetan, Rerata tekanan darah sistolik pre tes adalah $161 \mathrm{mmHg}$ dan post tes 149 $\mathrm{mmHg}$, diuji dengan paired t test menunjukkan $\mathrm{p}=0,013$ dan rerata tekanan darah diastolik pre tes adalah $83 \mathrm{mmHg}$ dan post test $79 \mathrm{mmHg}$, uji paired $t$ test menunjukkan $\mathrm{p}=0,037$ sehingga menunjukkan terapi berkebun efektif terhadap perubahan tekanan darah pada lansia dengan hipertensi (Sari et al., n.d.2014).

Terapi berkebun memberi kepuasan emosional saat panen, rasa memiliki, mendorong adanya komunikasi karena dilakukan bersama-sama, yang merupakan bentuk ekspresi diri yang dapat memungkinkan penyaluran bagi emosi sehingga menimbulkan rasa nyaman. Perasaan nyaman, tenang dan bahagia akan mengaktifkan HPA axis. HPA axis akan merangsang hipotalamus sehingga menurunkan sekresi CRH (Corticotropin Releasing Hormone) menyebabkan ACTH (Adrenocorticotropic Hormone) menurun dan merangsang POMC(Pro-opimelanocortin) yang juga menurunkan produksi ACTH dan kortisol sehingga menstimulasi produksi endorphin. Endorphin menimbulkan dilatasi vascular Penurunan kortisol dan ACTH serta peningkatan endorphin membuat pembuluh darah rileks sehingga akan menurunkan tahanan perifer dan cardiac output sehingga mempengaruhi tekanan darah (Sari et al., n.d.2014).

\section{METODE}

Penelitian ini menggunakan desain Quasi experimental pre-post test dengan kelompok kontrol. Tekanan darah diobservasi sebelum dan setelah diberikan perlakuan sebanyak 4 kali pertemuan selama 2 minggu. Penelitian ini dilaksanakan di Panti Sosial Tresna Werdha Minaula Kendari pada tanggal 25 Januari-7 Februari 2018. Populasi pada penelitian ini berjumlah 22 orang yaitu lansia dengan hipertensi di Panti Sosial Tresna. Pengambilan sampel menggunakan teknik non probability sampling dengan menggunakan metode purposive sampling. Sampel dari penelitian ini diambil dari populasi yang sudah memenuhi kriteria inklusi sebanyak 15 orang. Kriteria inklusi dalam penelitian ini antara lain: 1) Memiliki riwayat hipertensi (TDS $\geq 140$ $\mathrm{mmHg}$ ) dan pada saat pengukuran termasuk dalam kategori hipertensi stage 1,2) Mandiri dalam beraktivitas sehari-hari dan kooperatif, 3) Tidak mengalami kelemahan fisik. Variabel independen dalam penelitian ini adalah Terapi Berkebun. Variabel dependen dalam penelitian ini adalah tekanan darah lansia. Pengukuran variabel dependen pada penelitian ini menggunakan sphygmomanometer dan stetoskop. Hasil dari tekanan darah dicatat dalam lembar observasi. Pemberian terapi berkebun mengacu pada . Alat dan bahan yang dipergunakan meliputi polybag, media tanam, pupuk NPK, sekop mini, bibit tanaman kangkung dan air untuk menyiram tanaman. Penentuan jumlah responden berdasarkan kriteria inklusi dilakukan secara langsung saat pengukuran tekanan darah pada pengambilan data awal. Terapi berkebun dilakukan sebanyak 4 kali pertemuan selama 2 minggu dengan tahapan yaitu menyiapkan media tanam, persiapan bibit dan penanaman, pemeliharaan tanaman dan pemanenan. Total waktu setiap pertemuan adalah 75 menit, dengan pembagian 30 menit untuk pemeriksaan tekanan darah dan 45 menit untuk pelaksanaan terapi berkebun. Pengukuran tekanan darah diukur sebelum dan sesudah terapi berkebun pada kelompok kontrol dan intervensi sampai pertemuan keempat. Data 
yang diperoleh kemudian dianalisis menggunkan uji statistikPaired t-test dan independent $t$ test $(\alpha=0,05)$.

\section{HASIL PENELITIAN}

Hasil penelitian disajikan dan dianalisis dalam bentuk tabel dan dianalisis secara univariat dan bivariat. Hasil Penelitian menunjukan karakteristik responden penelitian berdasarkan usia dan jenis kelamin yang ditampilkan pada tabel berikut:

Tabel 1. Karakteristik Responden Berdasarkan Jenis Kelamin di Panti Sosial Tresna Werdha Minaula Kendari

\begin{tabular}{lcc}
\hline \multicolumn{1}{c}{ Karakteristik } & $\mathrm{n}$ & $\%$ \\
\hline Jenis kelamin & & \\
\hline Laki-laki & 5 & 33,3 \\
Perempuan & 10 & 66,7 \\
\hline Usia (tahun) & & \\
\hline $70-74$ & 9 & 60 \\
$75-90$ & 5 & 33,3 \\
$>90$ & 1 & 6,7 \\
\hline
\end{tabular}

Berdasarkan tabel 1 di atas pada karakteristik jenis kelamin, menunjukan bahwa responden yang berjenis kelamin laki-laki sebanyak 5 orang $(33,3 \%)$ dan perempuan sebanyak 10 orang $(66,7 \%)$. Hal tersebut menyimpulkan bahwa responden yang berjenis kelamin perempuan lebih banyak dibandingkan dengan responden yang berjenis kelamin laki- laki. Pada yang berjenis kelamin laki-laki. Pada karakteristik usia menunjukan bahwa responden yang berusia 60-74 tahun sebanyak 9 orang $(60 \%)$, responden yang berusia 75-90 tahun adalah sebanyak 5 orang $(33,3 \%)$ dan responden yang berusia $>90$ tahun sebanyak 1 orang $(6,7 \%)$. Hal tersebut menyimpulkan bahwa responden penelitian ini terbanyak berusia 60-74 tahun.

Tabel 2. Analisis pengaruh terapi berkebun terhadap perubahan tekanan darah lansia sebelum dan sesudah terapi berkebun pada kelompok intervensi di Panti Sosial Tresna Werdha Minaula Kendari.

\begin{tabular}{llcccc}
\hline Pertemuan & & I & II & III & IV \\
\hline \multirow{2}{*}{ Pre test } & TDS & $145,7 \mathrm{mmHg}$ & $130 \mathrm{mmHg}$ & $138,5 \mathrm{mmHg}$ & $147,1 \mathrm{mmHg}$ \\
\cline { 2 - 6 } & TDD & $74,2 \mathrm{mmHg}$ & $74,2 \mathrm{mmHg}$ & $80 \mathrm{mmHg}$ & $82,8 \mathrm{mmHg}$ \\
\hline \multirow{2}{*}{ Post test } & TDS & $130 \mathrm{mmHg}$ & $125,7 \mathrm{mmHg}$ & $127,1 \mathrm{mmHg}$ & $138,5 \mathrm{mmHg}$ \\
\cline { 2 - 6 } & TDD & $68,5 \mathrm{mmHg}$ & $72,8 \mathrm{mmHg}$ & $70 \mathrm{mmHg}$ & $75,7 \mathrm{mmHg}$ \\
\hline \multirow{2}{*}{$P_{\text {Value }}$} & TDS & 0,005 & 0,180 & 0,015 & 0,017 \\
\cline { 2 - 6 } & TDD & 0,231 & 0,655 & 0,018 & 0,025 \\
\hline
\end{tabular}

Uji paired t test dan Uji wilcoxon

Pada tabel 2 menjelaskan bahwa berdasarkan uji paired $t$ test pada tekanan darah sistolik lansia sebelum dan sesudah terapi berkebun di pertemuan pertama diperoleh nilai dengan nilai rata-rata tekanan darah sistolik sebelum terapi berkebun yaitu $130 \mathrm{mmHg}$ dan setelah terapi berkebun yaitu $125,7 \mathrm{mmHg}$. Sedangkan untuk uji $p=0,005$ dengan nilai rata-rata tekanan Darah sistolik sebelum diberikan terapi berkebun yaitu 145,7 danSesudah terapi berkebun yaitu $130 \mathrm{mmHg}$. Sedangkan untuk uji paired $t$ test pada tekanan darah diastolik lansia sebelum dan sesudah terapi berkebun di pertemuan pertama diperoleh nilai $p=0,231$ dengan nilai rata-rata tekanan darah diastolic sebelum terapi berkebun yaitu $74,2 \mathrm{mmHg}$ dan sesudah terapi berkebun yaitu 68,5 $\mathrm{mmHg}$. Pada pertemuan kedua diperoleh informasi nilai $p=0,180$ dengan nilai rata-rata tekanan darah sistolik sebelum terapi berkebun yaitu 130 $\mathrm{mmHg}$ dan setelah terapi berkebun yaitu 125,7 mmHg. Sedangakan untuk uji wilcoxon pada 
tekanan darah diastolik lansia sebelum dan sesudah terapi berkebun di pertemuan kedua diperoleh informasi nilai $p=0,655$ dengan nilai rata-rata tekanan darah diastolik sebelum terapi yaitu 74,28 $\mathrm{mmHg}$ dan sesudah terapi berkebun yaitu $72,85 \mathrm{mmHg}$.

Pada pertemuan ketiga setelah dilakukan uji paired t test pada tekanan darah sistolik lansia sebelum dan sesudah terapi berkebun diperoleh nilai $p=0,015$ dengan nilai rata-rata tekanan darah sistolik sebelum terapi berkebun yaitu $138,5 \mathrm{mmHg}$ dan setelah terapi berkebun yaitu $127,1 \mathrm{mmHg}$. Sedangkan untuk uji paired t test pada tekanan darah diastolik lansia sebelum dan sesudah terapi berkebun di pertemuan ketiga diperoleh nilai $p=0,018$ dengan nilai rata-rata tekanan darah diastolik sebelum terapi berkebun yaitu $80 \mathrm{mmHg}$ dan setelah terapi berkebun yaitu $70 \mathrm{mmHg}$.

Pada pertemuan keempat setelah dilakukan uji paired t test pada tekanan darah sistolik lansia sebelum dan sesudah terapi berkebun diperoleh nilai $p=0,017$ dengan nilai rata-rata tekanan darah sistolik sebelum terapi berkebun yaitu $147,14 \mathrm{mmHg}$ dan setelah terapi berkebun yaitu $138,57 \mathrm{mmHg}$. Sedangkan untuk uji Wilcoxon Pada tekanan darah diastolik lansia sebelum dan sesudah terapi berkebun diperoleh nilai $p=$ 0,025 rata-rata tekanan darah diastolik sebelum terapi berkebun yaitu $82,8 \mathrm{mmHg}$ dan setelah terapi berkebun yaitu $75,7 \mathrm{mmHg}$.

Tabel 3. Analisis uji perbedaan tekanan darah sistolik dan diastolik antara kelompok intervensi dan kontrol di Panti Sosial Tresna Werdha Minaula Kendari

\begin{tabular}{llcccc}
\hline & Pertemuan & I & II & III & IV \\
\hline \multirow{2}{*}{ Selisih TDS } & Kelompok intervensi & 9,9 & 8,2 & 10,3 & 8,5 \\
\cline { 2 - 6 } & Kelompok kontrol & 6,3 & 7,7 & 5,9 & 8,7 \\
\hline \multirow{2}{*}{ Selisih TDD } & Kelompok intervensi & 5,7 & 1,4 & 9 & 8,6 \\
\cline { 2 - 6 } & Kelompok kontrol & $-8,3$ & 1,2 & 7 & 7,4 \\
\hline \multirow{2}{*}{$P_{\text {Value }}$} & TDS & 0,107 & 0,813 & 0,045 & 0,237 \\
\cline { 2 - 6 } & TDD & 0,184 & 0,875 & 0,351 & 0,564 \\
\hline
\end{tabular}

Uji independent t test dan mann-whitney

Pada tabel 3 menjelaskan bahwa nilai selisih tekanan darah sistolik pada kelompok intervensi di pertemuan pertama adalah 9,9 sedangkan pada kelompok kontrol adalah 6,3 dengan hasil uji statistik menggunakan uji mann-whitney diperoleh nilai $p=0,107$. Adapun nilai selisih tekanan darah diastolicpada kelompok intervensi di pertemuan pertama adalah 5,7 sedangkan pada kelompok kontrol adalah $-8,3$ dengan hasil uji statistik menggunakan independent $t$ test diperoleh nilai $p=0,184$. Pada pertemuan kedua nilai selisih tekanan darah sistolik pada kelompok intervensi adalah 8,2. Sedangkan nilai selisih tekanan darah sistolik pada kelompok kontrol di pertemuan kedua adalah 7,7 dengan hasil uji statistik menggunakan uji mann-whitney diperoleh nilai $p=0,813$. Adapun nilai selisih tekanan darah diastolik pada kelompok intervensi di pertemuan kedua adalah 1,4. Sedangkan nilai selisih tekanan darah diastolik pada kelompok kontrol adalah 1,2 dengan hasil uji statistik menggunakan uji independent $t$ test diperoleh nilai $p=0,875$.

Pada pertemuan ketiga nilai selisih tekanan darah sistolik pada kelompok intevensi adalah 10,3. Sedangkan nilai selisih tekanan darah sistolik pada kelompok control di pertemuan ketiga adalah 5,9 dengan hasil uji statistik menggunakan uji mann-whitney diperoleh nilai $p=0,045$. Adapun nilai selisih tekanan darah diastolik pada kelompok intervensi di pertemuan ketiga adalah 9. Sedangkan nilai selisih tekanan darah sistolik pada kelompok kontrol adalah 7 dengan hasil uji statistik menggunakan uji mann-whitney diperoleh nilai $p=0,351$.

Pada pertemuan keempat nilai selisih tekanan darah sistolik kelompok intervensi adalah 8,5 dan pada kelompok kontrol adalah 8,7 dengan hasil uji statistik menggunakan uji independent $t$ test diperoleh nilai $p=0,237$. Adapun nilai selisih tekanan darah diastolik pada kelompok intervensi di pertemuan keempat adalah 8,6 dan 
pada kelompok kontrol adalah 7,4 dengan hasil uji statistik menggunakan uji mann-whitney diperoleh nilai $p=0,564$.

\section{PEMBAHASAN}

Penelitian ini dilakukan untuk untuk mengetahui pengaruh terapi berkebun terhadap perubahan tekanan darah pada lansia dengan hipertensi dan mengetahui perbedaan tekanan darah antara kelompok kontrol dan kelompok intervensi di Panti Sosial Tresna Werdha Minaula Kendari.

Pada hasil penelitian ini didapatkan responden yang mengalami perubahan tekanan darah sistolik di pertemuan pertama sebanyak 6 reponden dan responden yang nilai tekanan darah sistoliknya tetap setelah terapi berkebun sebanyak 1 responden saja, sehingga berdasarkan uji statistik paired $t$ test untuk tekanan darah sistolik diperoleh nilai $p=0,005$ yang menunjukan bahwa terdapat pengaruh terapi berkebun terhadap penurunan tekanan darah sistolik pada pertemuan pertama. Hal ini sejalan dengan penelitian yang dilakukan oleh Sari A.P dkk (2014), dimana terdapat pengaruh terapi berkebun terhadap penurunan tekanan darah sistolik lansia dengan nilai $p=0,013$. Artinya bahwa terapi berkebun efektif dalam menurunkan tekanan darah sistolik Lansia. Melihat keindahan dan melakukan kontak langsung dengan tanaman dapat memicu ketenangan dan kedamaian, memicu emosi positif, dan mengalihkan fokus dari stres.Sedangkan hasil uji statistik paired t test untuk tekanan darah diastolik diperoleh nilai $p$ $=0,231$, sehingga dapat disimpulkan bahwa tidak ada pengaruh terapi berkebun terhadap perubahan tekanan darah diastolik lansia pada pertemuan pertama. Hasil penelitian ini bertolak belakang dengan penelitian yang dilakukan oleh Sari A.P (2014) yang menunjukan bahwa terdapat pengaruh terapi berkebun terhadap penurunan tekanan darah diastolik dengan nilai $p=0,037$. Tidak adanya pengaruh terapi berkebun terhadap tekanan darah distolik diakibatkan karena berkebun adalah aktivitas fisik yang tidak semua Lansia tertarik pada kegiatan tersebut sehingga menyebabkan masih ada beberapa Lansia memiliki tekanan darah diastolik tidak berubah. Kurangnya aktivitas fisik meningkatkan risiko menderita tekanan darah tinggi (hipertensi) karena meningkatkan risiko kelebihan berat badan. Orang yang tidak aktif juga cenderung mempunyai frekuensi denyut jantung yang lebih tinggi sehingga otot jantungnya harus bekerja lebih keras pada setiap kontraksi. Makin keras dan sering otot jantung harus memompa, makin besar tekanan yang dibebankan pada arteri. Teori tersebut menunjukkan bahwa aktivitas fisik dapat berpengaruh terhadap perubahan tekanan darah (Phillips, 2009).

Mengolah media tanam merupakan aktivitas fisik ringan, sehingga selama kegiatan tersebut didapatkan tekanan darah responden mengalami perubahan, meskipun pada tekanan darah diastolik hanya ada 2 responden yang tekanan darahnya menurun setelah melakukan terapi berkebun di pertemuan pertama.

Pada pertemuan kedua di minggu pertama dilakukan terapi berkebun yaitu tahapan persiapan bibit dan penanaman. Berdasarkan hasil uji statistik menggunkan uji wilcoxon didapatkan nilai $p=0,180$ dimana nilai signifikan $p>0,05$, maka dapat disimpulkan bahwa terapi berkebun pada tahapan persiapan bibit dan penanaman di pertemuan kedua tidak memiliki pengaruh Hal yang sama juga terjadi pada hasil tekanan darah diastolik lansia pada pertemuan kedua, dimana diperoleh nilai $p=$ 0,180 dimana nilai signifikan $p>0,05$. Hasil penelitian ini bertolak belakang dengan penelitian yang dilakukan oleh Yusuf, R.A. (2013) yang dilakukan di Malang pada 9 orang lansia, dari penelitian yang dilakukan diperoleh hasil uji statistik paired $t$ test dimana nilai $p=$ 0,000 (Yusuf.R.A.W, 2013).

Pelaksanaan terapi berkebun pada pertemuan kedua didapatkan hasil yang bertolak belakang dengan penelitian sebelumnya. Hal ini dikarenakan pada tahapan ini yaitu tahapan persiapan bibit dan penanaman, responden tidak bersemangat dan kurang aktif. Pada tahapan 
persiapan bibit dan penanaman memang sangatlah sederhana karena peneliti menggunakan bibit yang masih dalam bentuk biji sehingga responden terlihat tidak terlalu tertarik pada saat pelaksanaan terapi berkebun di pertemuan kedua.

Pertemuan ketiga di minggu kedua yaitu pada tahapan pemeliharaan tanaman yaitu proses pemupukan tanaman dimana berdasarkan hasil uji statistik dengan menggunakan uji paired $t$ test diperolah nilai $p=0,015$ dimana nilai signifikan $p>0,05$ maka dapat disimpulkan bahwa ada pengaruh terapi berkebun terhadap perubahan tekanan darah sistolik lansia pada pertemuan ketiga. Hal yang sama juga terjadi pada hasil tekanan darah diastolik lansia, dimanaberdasarkan hasil uji statistik dengan menggunkan paired $t$ test diperoleh nilai $\mathrm{p}=$ 0,018 dimana nilai signifikan $p>0,05$, maka dapat disimpulkan bahwa ada pengaruh terapi berkebun terhadap perubahan tekanan darah diastolik lansia pada pertemuan ketiga.

Pertemuan berikutnya adalah pertemuan keempat yaitu tahap pemanenan dimana berdasarkan hasil uji statistik paired $t$ test diperolah nilai $p=0,017$ dimana nilai signifikan $p>0,05$ maka dapat disimpulkan bahwa ada pengaruh terapi berkebun terhadap perubahan tekanan darah sistolik pada lansia di pertemuan keempat. Hal yang sama juga terjadi pada hasil pengukuran tekanan darah diastolik lansia sebelum dan sesudah melakukan terapi berkebun di pertemuan keempat dimana berdasarkan hasil uji statistik dengan menggunakan uji wilcoxon diperoleh nilai $p=$ 0,025 dimana nilai signifikan $p>0,05$ maka dapat disimpulkan bahwa ada pengaruh terapi berkebun terhadap perubahan tekanan darah diastolic lansia pada pertemuan keempat. Pada tahapan ketiga dan keempat yaitu tahapan pemeliharaan, tanaman dan pemanenan, pemeliharaan tanaman selain dilakukan penyiraman setiap dua kali sehari, juga dilakukan pemupukan dengan menggunakan pupuk NPK, pada tahapan ini responden terlihat sangat aktif dan bersemangat pada saat pemupukan, dikarenakan tanaman kangkung tumbuh subur dan semua tanaman tumbuh dengan baik, warnanya yang hijau membuat lansia merasa tenang dan nyaman. Hal yang sama juga terjadi pada pelaksanaan terapi berkebun dipertemuan keempat pada saat panen, responden merasa puas dan terlihat bahagia karena tanaman kangkung yang mereka tanam sendiri dapat tumbuh dengan dengan baik sampai saat panen tiba. Rasa tenang, nyaman dan bahagia inilah yang memicu tubuh untuk mengaktifkan HPA axis. HPA axis akan merangsang hipotalamus sehingga menurunkan sekresi CRH (Corticotropin Releasing Hormone) menyebabkan ACTH (Adrenocorticotropic Hormone) menurun dan merangsang POMC (Pro-opimelanocortin) yang juga menurunkan produksi ACTH dan kortisol sehingga menstimulasi produksi endorphin. Endorphin menimbulkan dilatasi vascular penurunan kortisol dan ACTH serta peningkatan endorphin membuat pembuluh darah rileks sehingga akan menurunkan tahanan perifer dan cardiac output sehingga mempengaruhi tekanan darah (Sari et al., n.d. 2014).

Berdasarkan hasil analisis uji perbedaan tekanan darah sistolik antara kelompok kontrol dan kelompok intervensi di Panti Sosial Tresna Werdha Minaula Kendari ditemukan perbedaan yang signifikan tekanan sistolik antara kelompok kontrol dan intervensi pada pertemuan ketiga, hal ini dibuktikan dengan hasil uji statistic menggunakan uji mannwhitney diperoleh nilai $p=0,045$ dimana nilai $p>0,05$. Sedangkan untuk hasil analisis uji perbedaan tekanan darah diastolik antara kelompok kontrol danintervensi pada pertemuan ketiga tidak ditemukan perbedaan yang signifikan tekanan darah diastolik antara kelompok kontrol dan intervensi. Hal ini dibuktikan dengan hasil uji statistik menggunakan uji mann-whitney diperoleh nilai $p=0,351$ dimana nilai $\mathrm{p}>0,05$.

Sedangkan pada pertemuan pertama, kedua, dan keempat juga tidak ditemukan perbedaan yang signifikan tekanan darah sistolik dan diastolik antara kelompok kontrol dan 
intervensi. Hal ini dibuktikan dengan nilai $p$ berikut ini secara berurut $p_{1}$ TDS $=0,107, p_{1}$ $\mathrm{TDD}=0,184, p_{2}$ TDS $=0,831, p_{2} \mathrm{TDD}=$ $0,875, p_{4}$ TDS $=0,237$ dan $p_{4}$ TDD $=0,564$. Sehingga dapat disimpulkan bahwa secara statistik tidak ada perbedaan yangbermakna tekanan darah sistolik dan diastolik anatara kelompok kontrol dan kelompok intervensi pada pertemuan pertama, kedua dan keempat. Hal ini dikarenakan waktu pelaksanaan terapi berkebun hanya berlangsung selama dua minggu dimana waktu ini dirasa kurang cukup oleh peneliti untuk melihat perbedaan tekanan darah sistolik dan diastolik antara kelompok intervensi dan kelompok kontrol sesudah terapi berkebun. Variasi perubahan tekanan darah responden dapat disebabkan karena adanya perbedaan gaya hidup seperti konsumsi kafein, kurang olah raga dan stres juga konsumsi obat anti hipertensi, hal tersebut merupakan variabel perancu yang tidak dapat dikontrol sepenuhnya oleh peneliti. Tekanan darah responden baik itu kelompok kontrol dan intervensi selama penelitian selalu naik turun dan selalu berbeda pada setiap pertemuan,hal ini disebabkan karena banyak faktor yang mempengaruhi tekanan darah lansia, diantaranya karena faktor makanan dimana ke 15 responden mengatakan bahwa makanan yang disediakan oleh panti memiliki kadar garam yang tinggi, hal ini dikarenakan makanan antara lansia yang mengalami hipertensi dan yang tidak mengalami hipertensi tidak dibedakan oleh pihak panti. Lansia dengan hipertensi dianjurkan untuk mengurangi konsumsi garam.

Dalimartha dan Setiawan (2008) menyatakan bahwa garam bersifat menahan air. Konsumsi garam yang berlebihan dengan sendirinya akan menaikkan tekanan darah. Natrium berhubungan dengan kejadian tekanan darah tinggi karena konsumsi natrium dalam jumlah yang tinggi dapat mengecilkan diameter dari arteri, sehingga jantung harus memompa lebih keras untuk mendorong volume darah yang meningkat melalui ruang yang semakin sempit dan akan menyebabkan tekanan darah meningkat. Faktor yang mempengaruhi tekanan darah lansia pada penelitian ini, selain dari konsumsi garam yang tinggi responden juga memiliki kebiasaan mengonsumsi minuman berkafein yaitu berupa kopi, dalam sehari responden mengonsumsi kopi sebanyak tiga gelas bahkan lebih (Dalimartha, 2008).

Menurut Mannan H. dkk (2012), menjelasakan bahwa salah satu faktor risiko terjadinya hipertensi yang dapat diubah adalah kebiasaan minum kopi. Kopi mengandung senyawa kafein yang bisa menyebabkan tekanan darah meningkat tajam (Mannan, Wahiduddin, 2012). Faktor lain yang mempengaruhi tekanan darah meningkat tajam. Faktor lain yang mempengaruhi tekanan darah pada lansia selama penelitian ini adalah kebiasaan merokok. Nikotin bisa mengakibatkan gangguan pada jantung, mempercepat aliran darah, membuat irama jantung menjadi tidak teratur, membuat kerusakan pada pembuluh darah dan mengakibatkan penggumpalan darah melalui mekanisme arterosklerosis, gangguan metabolisme lemak, gangguan sistem hemostatik, dan penurunan kemampuan untuk oksigenasi. Hal ini dipengaruhi jumlah rokok yang dihisap dan lamanya kebiasaan merokok. Kebiasaan merokok meningkatkan resiko hipertensi sebanyak 2 sampai 3 kali (Stefhany, 2017). Penjelasan tersebut adalah sebagian kecil dari sekian banyaknya faktor perancu yang dapat mempengaruhi tekanan darah.

\section{KESIMPULAN}

Kesimpulan pada penlitian ini adalah Terdapat pengaruh terapi berkebun terhadap perubahan tekanan darah lansia dengan hipertensi di pertemuan pertama, ketiga, keempat untuk tekanan darah sistolik dan pertemuan ketiga, keempat untuk tekanan darah diastolik dan tidak terdapat pengaruh terapi berkebun terhadap perubahan tekanan darah lansia dengan hipertensi di pertemuan pertama untuk tekanan darah diastolik dan pertemuan kedua untuk tekanan darah sistolik dan diastolik di Panti Sosial Tresna Werdha Minaula Kendari. Terdapat perbedaan tekanan darah pada kelompok kontrol dan intervensi di pertemuan 
ketiga untuk tekanan darah sistolik dan untuk tekanan darah sistolik dan tidak ada di pertemuan ketiga untuk tekanan darah sistolik dan tidak ada perbedaan tekanan darah pada kelompok kontrol dan intervensi pada pertemuan pertama, kedua, keempatuntuk tekanan darah sistolik dan pertemuan pertama, kedua, ketiga, dan keempat untuk tekanan darah diastolik di Panti Sosial Tresna Werdha Minaula Kendari.

\section{SARAN}

Perlu dilakukan penelitian lebih lanjut tentang pengaruh terapi berkebun terhadap perubahan tekanan darah pada lansia dengan hipertensi dengan melakukan pengawasan terhadap faktor yang mempengaruhi tekanan darah seperti mengontrol konsumsi garam, kafein, kebiasaan merokok, dan stressor bagi penderita hipertensi secara tepat. Penelitian selanjutnya diharapkan dapat mengamplikasikan terapi berkebun tidak hanya pada lansia yang mengalami hipertensi tetapi juga dapat dilakukan pada kelompok umur lainnya yang mengalami hipertensi.

\section{REFERENSI}

1. Agustina, S. (2014). Faktor-Faktor yang Berhubungan dengan Hipertensi Pada Lansia di Atas Umur 65 Tahun Factors Related with Hypertension on The Elderly over 65 Years. Jurnal Kesehatan Komunitas, 2(01), 2-7. Retrieved from jurnal.htp.ac.id/index.php/keskom/article/do wnload/70/57/

2. Dalimartha, S. (2008). Care your Self Hipertensi (edisi 1). Jakarta: Penebar Plus Positif.

3. H, A. M., \& Nisa, K. (2017). Pengaruh Musik Klasik Terhadap Penurunan Tekanan Darah pada Lansia Penderita Hipertensi Effect of Classical Music to Decrease of Blood Pressure in Elderly Patients with Hypertension, 4.

4. Hasrin Mannan, Wahiduddin, R. (2012). Faktor Risiko Kejadian Hipertensi di Wilayah Kerja Puskesmas Bangkala Kabupaten Jeneponto Tahun 2012, 2(11), 19-21.
5. Nations, U. (2015). World Population Ageing 2015.

6. Phillips, K. (2009). Bad Money - Reckless Finance, Failed Politics, and the Global Crisis of American Capitalism, 5(1), 256. https://doi.org/10.1002/9781444324808.ch3 6

7. Sari, A. P., Wahyuni, E. D., Perubahan Tekanan Darah Pada Lansia Dengan Hipertensi Melalui Therapeutical Gardening di UPT PSLU MAGETAN. Jurnal Unair.

8. Stefhany, E. (2017). Hubungan Pola Makan, Gaya Hidup, Dan Indeks Massa Tubuh Dengan Hipertenesi Pada Pra Lansia Dan Lansia Di Posbindu Kelurahan Depok Jaya, $1-15$.

https://doi.org/10.1179/1754762814Y.00000 0007

9. Yusuf.R.A.W, Perbedaan Tekanan Darah Pada Lansia Sebelum dan Sesudah Dilakukan Horticultural Therapy di RAAL (Rumah Asuh Anak dan Lansia) GRIYA ASIH_LAWANGYonata, A., \& Pratama, A. S. P. (2016). Hipertensi sebagai Faktor Pencetus Terjadinya Stroke. Jurnal Majority, 5(3), 17-21. Retrieved from http://juke.kedokteran.unila.ac.id/index.php/ majority/article/view/1030/824 